\title{
New Analysis of Capital Flight from Saudi Arabia: The Relation with Long-Term Economic Performance
}

\author{
Abdullah Hussein Almounsor \\ Correspondence: Abdullah Hussein Almounsor, College of Business, Albaha University, PO Box 1988, Al Baha 65431, \\ Saudi Arabia.
}

Received: August 10, 2017

Accepted: September 14, $2017 \quad$ Available online: September 17, 2017

doi:10.11114/aef.v4i6.2656

URL: https://doi.org/10.11114/aef.v4i6.2656

\begin{abstract}
This research provides new estimates of illicit capital flight from Saudi Arabia using the Residual methodology and accounts for the social opportunity cost of those unregulated funds in terms of forgone economic growth by utilizing the Incremental Capital-Output Ratio (ICOR) approach. The empirical findings reveal that over the period 1971-2015, capital flight from Saudi Arabia reached over 212 billion of 2010 USD, causing an annual average of 3.57 percent of wasted potential additional economic growth for the same period. When considering the median instead, an incremental 1.72 percent would have been added annually to the aggregate output growth in Saudi Arabia had capital flight not taken place with the observed pattern during the analysis period. The research concludes with important suggestions for extending this work and crucial remarks for policymakers to tackle unregulated cross-border capital flows and minimize the related consequences. Critical policy measures include coordination with trading partners and key investment destination for Saudi capital flows, as well as strengthening of the regulatory framework for cross-border financial transactions based on best international practices.
\end{abstract}

Keywords: capital flight, economic growth, Saudi Arabia, ICOR, the Residual approach

\section{Introduction}

The issue of capital flight from developing countries has received renewed attention of scholars and international organizations. While economic theory suggests the direction of capital flows should be from the rich (capital abundant) developed countries to the less developed (capital scarce) countries, new empirical studies have proved otherwise. Indeed, many developing and less-developed countries have been found to be net creditors to the world through unregulated capital flows ( e.g., see Epstein 2005; Boyce and Ndikumana, 2000, 2010, and Almounsor, 2005, 2008).

While facing financing constraints, many developing countries continue to leak financial resources in the form of illicit and unregulated capital flows to the rest of the world. Considered as dissaving, capital flight reduces the stock of financial resources available for productive domestic investment and spending, thereby undermining capacity for economic growth and development. Many scholars have also attributed sluggish economic growth and persistent balance of payments deficits in developing countries to capital flight (Onwidoduokit, 2001). In addition, capital flight can destabilize the domestic interest rate and exchange rate, which weakens the effect of financial policies (Cuddington, 1986, and Pastor, 1990).

Capital flight also undermines good governance, fosters corruption, contributes to uncertainty and instability, and reduces capacity for provision of public services. In addition, the loss of capital flows can erode the domestic tax base and widen income and social inequality by redistributing income from the poor to the rich (Pastor, 1990; Ajayi, 1997). The concealment of such cross border financial flows is in itself a concern for developing countries because it signals a great deal of underlying problems that need long term treatment.

This research provides new and extended estimates of capital flight from Saudi Arabia and assesses the potential impact of capital flight on socioeconomic conditions. In particular, the research simulates the impact of capital flight on economic growth, using the Financing Gap Approach based on the well-known Harrod-Domar Model. As such, the calibration shows how much income per capita would have been generated if all the illicit funds transferred abroad were geared toward domestic investment, assuming the same productivity of actual investment.

There are three major contributions of this research to the literature. First, it sheds light on the issue of capital flight as a serious and often overlooked problem in the context of the Gulf Cooperation Council Countries (GCC). Second, it 
provides new calculation of capital flight from Saudi Arabia over an extended period of time not found earlier in the literature. Third, the research provides the first calibration of the opportunity cost of capital flight in Saudi Arabia in terms of forgone output.

The results of this work suggest that the Saudi economy has experienced large amounts of capital flight in the last four decades. In addition, the findings indicate that capital flight has non-trivial and negative consequences on the long-term economic performance of Saudi Arabia. Accordingly, important policy measures must be taken to curtail or prevent capital flight from Saudi Arabia and therefore help keep necessary resources within the domestic economy.

This research proceeds in the following way: section 2 reviews the literature on capital flight and its connection to economic growth; section 3 provides the methodologies of estimating unregulated capital flows and simulating the impact on economic growth; in section 4 the empirical findings are discussed and analyzed; the last section concludes with important remarks, future research suggestions, and policy implications.

\section{Literature Review on Capital Flight and Its Implications}

Capital flight is defined here as the transfer of assets abroad in order to reduce loss of principal, loss of return, or loss of control over one's financial wealth due to government-sanctioned activities (Epstein, 2005). As such, capital flight consists of international capital flows that try to escape the control of domestic authorities. For developing countries in general, several research papers have estimated and analyzed capital flight in different settings (e.g. Boyce and Ndikumana 2000, 2010, Epstein 2005; and Nkurunziza 2014). For Saudi Arabia, only two previous studies by the same author (Almounsor 2005; 2008) have provided estimates of capital flight and drawn some policy implications in the context of the resource-based Middle Eastern economies.

In Almounsor 2005, capital flight in Saudi Arabia were estimated at 11.8 billion of 1995 USD, over the analysis period 1971 - 2001. For the resource-based economies of the MENA region as a whole, capital flight amounted to 273 billion of 1995 USD, averaging 9.4 percent of GDP on an annual basis. According to Almounsor (2008), Capital flight in the oil-based economies is fueled mainly by the proceeds of oil exports in foreign exchange, the single most important source of capital inflows in those countries. As such, the largest amounts of capital flight were indeed during the times when those countries enjoyed unprecedented amounts of crude oil exports in foreign exchange. In particular, the decade of the 1970s and into the early 1980s accounts for most capital outflows from the resource-based economies of the MENA region.

Almounsor (2008) recommends that the resource-based economies undertake appropriate measures to control capital flight and pave the way for capital flight reversal. Such reversal of capital would help finance industrialization and public development projects that create employment opportunities and enhance productive capacity. As suggested by the empirical analysis in Almounsor (2008), the oil-based countries of the sample can reduce capital flight by facilitating domestic investment opportunities that would stimulate economic growth and provide an incentive for capital to remain within the boundaries. In addition, economic diversification away from the reliance on the industrial sector and oil exports would help reduce capital flight significantly in those economies.

Beja (2007) provided estimates of capital flight from the Philippines from 1970 to 1999 of about 95 billion USD. Using the Residual Method and the ICOR approach, the results of this work suggests that the Philippines had lost between $\$ 432$ million to $\$ 864$ million of output, or an average loss in growth rate of 1 to 2.3 percent. As such, the author argues if the capital flight were used to finance productive domestic endeavors, the country would have realized stronger macroeconomic performance over the three decades of analysis. The author concludes that unless decisive policy actions are taken up to address the enduring capital flight, the Philippines would remain caught in the perpetuity of crises and would remain frustrated from realizing an economic takeoff.

Ajayi (2012) provides an analysis of capital flight and its impact on domestic investment and growth in Nigeria, using Cointegration and Error Correction Modelling. The findings indicate that capital flight has a negative impact on the Nigerian economy. Accordingly, the author recommends fiscal discipline and serious commitment on the part of government. In addition, the author suggests the government should provide enabling environment for business to thrive and encourage foreign direct investment to Nigeria.

Adetiloye, Kehinde (2012) undertake an empirical investigation of capital flight in Nigeria using variables of investment, exchange rates and others, using vector error correction mechanism and OLS regression analysis. The results indicate that capital flight has a negative but insignificant impact on domestic investment in Nigeria.

Olugbenga and Alamu (2013) present a critical examination of the impact of capital flight on Nigeria's economic growth over a period of 30 years (1981-2010), using the Johansen co-integration test. The Results show that there is a long run co-integration among the variables. In addition, capital flight has negative impact on economic growth only in the short run. However, the authors argue that capital flight significantly and positively influence Nigerian economic growth in the long run. According to the authors, this is justified by the importation of capital/industrial goods which when used 
translates into economic growth.

Salandy and Henry (2013) examine the impact of capital flight on investment and economic growth in Trinidad and Tobago over the period 1971-2008. In this work they provide an empirical investigation into the causal linkage among capital flight, domestic investment and economic growth. The authors use two estimation techniques: the Vector Error Correction (VEC) Model and the Generalized Method of Moments (GMM). The results point to a negative relationship between capital flight and domestic investment and between capital flight and economic growth. The authors argue that policy aimed at reducing capital flight can have a positive effect on domestic investment and therefore lead to increased levels of economic growth in Trinidad and Tobago.

Nidukumana (2013) examines the implications of capital flight and tax havens for economic development in 39 African countries over 1970-2010. In particular, the paper analyzes empirically the consequences of capital flight on domestic investment and the opportunity cost of capital flight in terms of forgone growth. The empirical results indicate that capital flight had a negative effect on domestic investment in a statistically significant way. As such, capital flight is found to be one of the factors that have contributed to the chronically low domestic investment in African countries over the past decades.

The simulation results based on the Financing Gap Model in Nidukumana (2013) indicate that investing capital flight domestically in the 39 African countries would have yielded an extra 2.4 percent annual growth rate on average and a median incremental annual GDP growth of 0.8 percent. The author then outlines a strategy to combat capital flight including the following: deterring illegal export of honestly acquired capital, addressing trade-related capital flight and tax evasion, tackling the revolving door and odious debt, and enforcing banking transparency and tax compliance in safe havens.

Wujung and Mbella (2013) investigate the relationship between capital flight and economic development in the Cameroon economy during the period 1970-2013. Applying the Fully Modified Least Squares (FMOLS) technique, the authors present evidence in support of a negative significant relationship between capital flight and economic development in Cameroon over the period of the study.

Nkurunziza (2014) has attempted to quantify the magnitude of the effect of capital flight on the rate of poverty reduction for 35 African countries, using the Incremental Capital Output Ratio (ICOR) and the capital stock-based method. The results of this work suggest that, on average, if capital flight were invested with the same efficiency as domestic investment, it would have helped reduce poverty by an additional 1.9 and 2.5 percent between 1999-2010. As such, the author contents that capital flight has significantly undermined the African countries' efforts to reduce poverty effectively.

Weeks (2014) assesses the impact of capital flight on growth in thirty-one sub-Saharan African countries. The analysis in this work fails to support the hypothesis that countries with sound fundamentals experience low capital flight. This research also develops a growth estimating equation derived from the Harrod-Domar framework. The growth estimations support the conclusion that capital flight had a major negative impact on growth over the last three decades, 1980-2010. The negative impact was greatest for the petroleum-exporting countries and those affected by internal conflict, but it was also substantial for the other countries, with a few exceptions.

Mpenya, Metseyem, and Ngah Epo (2015) estimate capital flight from natural resources (oil and wood) in the Cameroon and simulate the impact of capital flight on economic growth. They also estimate the potential growth achieved if capital flight were invested in the local economy, using the Incremental Capital Output Ratio (ICOR). The results indicate that the natural resources sector is a major source of capital flight in the Cameroon. In addition, if capital flight from the natural resource sector were reinvested domestically it would have generated, on average, 0.69 percentage of additional growth during 1995-2001 and about 0.76 percentage during 2002-2010.

\section{Research Methodology}

\subsection{Methodology of Estimating Capital Flight}

The Residual Approach developed by the World Bank in 1985 is used here to estimate capital flight from Saudi Arabia. According to this approach, capital flight is defined as the difference between recorded capital inflows and recorded foreign exchange outflows (Boyce and Ndikumana, 2000). The rationale behind such characterization lies in the argument based on the balance of payments identity that capital inflows are either used to finance current account deficits or accumulated in the central bank as foreign exchange reserves. Accordingly, capital inflows flows that do not go to either account are regarded as capital flight, which finances private external assets.

More specifically, a surplus of inflows over reported uses reflects capital flight. The residual here captures unrecorded flows and usually implies attempts to avoid rules, regulations and social control by local governments (Almounsor 2005). The starting point of estimating capital flight and thus private external assets is the balance of payments statistics 
of Saudi Arabia. To carry out the estimation, the Residual Measure is applied as follows:

$$
K F t=\Delta \text { DEBTt }+ \text { NFIt }-(C A t+\Delta R E S t)
$$

Where KFt refers to capital flight in current USD for Saudi Arabia in time period t; $\triangle$ DEBT refers to change in total external debt stock; NFIt refers to net inflows of foreign investment; CAt refers to the current account deficit; and $\Delta$ RESt refers to the changes in the accumulation of foreign exchange reserves (net additions).

Equation (1) calculates unrecorded net outflows of capital from Saudi Arabia. The use of unrecorded flows captures the notion that, by this definition, capital flight involves the attempt by wealth holders to avoid government policies. However, there might also be cases where wealth holders are motivated by the desire to avoid the control of domestic authorities and send funds abroad through recorded channels. As such, capital flight will consist of recorded and unrecorded outflows. This paper, however, calculates capital flight using only unrecorded outflows. Therefore, it is important to highlight that this measure, based on unrecorded capital flows, is a minimum estimate of capital flight and should be considered a floor on the likely degree of unofficially departed financial outflows.

The capital inflows in equation (1) are (the change in total external debt stock plus net inflows of foreign investment), whereas the recorded foreign exchange outflows are (financing the current account deficit and accumulating foreign exchange reserves in the central bank). If the difference is positive, this reflects capital flight; if it becomes negative, this implies net unrecorded capital inflows into the Saudi economy. Since there is no external debt data for Saudi for the period of analysis (1971-2015), the first term of equation 1 ( $\triangle \mathrm{DEBT})$ is disregarded.

However, the literature on capital flight has identified an important issue to be tackled in the calculation, which is trade-misreporting (misinvoicing). Misreporting the export and import transaction (for different motives) distorts the current account figures. For example, if the current account deficit is overstated (i.e., import over-invoicing or export under-invoicing), the capital flight estimates will be smaller in equation 1. Conversely, if the current account deficit is understated (i.e., import under-invoicing or export over-invoicing), the capital flight estimates will be higher in equation 1. To correct for trade misinvoicing in BOP data, a comparison is performed between Saudi export-import data and those of Saudi trading industrial partners, using the World Integrated Trade Solutions (WITS) database of the World Bank, and the Saudi Arabian Monetary Authority's data on foreign trade.

The assumption in the comparison exercise is that the data from industrialized countries trading partners are relatively more accurate, and the discrepancy between them and the Saudi trade data is interpreted as evidence of trade misinvoicing. For Saudi Arabia, in year, t, export and import discrepancies with industrial partners (North American and the European Union countries) are computed as follows:

$$
\begin{gathered}
\text { DEXPt }=\text { PEXPt }-(1+C I F t) * E X P t) \\
\text { DIMPt }=I M P t-(1+C I F t) * \text { PIMP } t) \\
\text { MISINVt }=(D E X P / I C X S)+(D I M P / I C M S)
\end{gathered}
$$

Where DEXP and DIMP refer to export and import discrepancies; PEXP and PIMP refer to exports and imports of Saudi Arabia recorded in industrial countries' official statistics; EXP and IMP are exports and imports of Saudi Arabia as reported in its own statistics; CIF refers to the cost of freight and insurance; and ICXS and ICMS refer to the share of Saudi Arabia's exports to industrial countries in total exports to the world and the share of Saudi imports from industrial countries in total imports from the world, respectively.

The cost of freight and insurance are standardized to 10 percent of the value of exports or imports throughout the computation. MISINV refers to global trade misinvoicing of Saudi Arabia. A positive sign of DEXP indicates net export under-invoicing; a negative sign indicates net export over-invoicing. Similarly, a positive sign of DIMP indicates net import over-invoicing; a negative sign indicates net import underinvoicing.

Thus, the trade data is corrected for Saudi Arabia and total trade misinvoicing is then added to the calculation of capital flight in equation (1) as follows:

$$
\text { KFAdj } t=K F t+\text { MISINVt }
$$

Lastly, the adjustment for inflation is done by transforming capital flight into constant 2010 USD using the US Producer Price Index (PPI). The rationale here is that a dollar that fled in, say, 1980, from Saudi Arabia, for instance, is worth more than a dollar that fled 20 years later. To make the value of capital flight comparable at different dates, they must be adjusted for inflation as follows: 


$$
\text { Real KFAdjt }=\text { KF Adjt / PPIt }
$$

All the data used are in annual frequency and described in Table A1 in the Appendix.

\subsection{Methodology of Calibrating the Social Cost of Capital Flight}

This section outlines the methodology used to quantify the potential effect of capital flight on socioeconomic conditions based on the Financing Gap Model following Nkurunziza (2014). The main assumption is that Saudi Arabia has a resource gap that needs to be filled in order to grow at higher rates. Investing flight capital could partly fill this gap. For a target growth rate, this model determines the financing gap between available and required levels of investment. As such, the Financing Gap Model is used to determine the potential growth in GDP that could result from additional investment represented by the amount of capital flight. Despite criticisms against this approach, the Financing Gap Model is widely used in international financial institutions, planning ministries, and central banks (Nkurunziza, 2014).

\subsubsection{ICOR-Based Simulation}

The Incremental Capital Output Ratio (ICOR) is defined as the amount of marginal capital investment needed to produce one additional unit of output (Nkurunziza (2014). Over a specific time period, ICOR is approximated as the ratio of average investment to average GDP growth. The ICOR methodology may also be seen as relating a target growth rate to a specific ratio of investment to gross domestic product (GDP), adjusting for the productivity of investment, as follows

$$
g t=\frac{I t / G D P t}{\pi t}
$$

Where $g \mathrm{t}$ is the growth rate of output, It is investment; GDPt is the gross domestic product; $\pi \mathrm{t}$ is the ICOR and subscript $t$ represent the year, where $t \in(1971, \ldots, 2015)$. Investment, GDP and the rate of economic growth are known and used to compute the ICOR as follows:

$$
\pi t=\frac{I t / G D P t}{g t}
$$

Low ICOR values imply that investment is more efficient: producing one unit of incremental output requires less incremental capital investment. Although straightforward, the computation of ICORs is associated with two major issues as outlined in Nkurunziza (2014). First, when rates of economic growth are negative, as has been the case for several years in many developing countries, the ICOR turns negative. Negative ICORs do not have any economic meaning. Hence, the computations relating investment to output in this paper exclude all observations with corresponding negative ICORs. Second, high volatility of growth and, to some extent, investment rates, leads to large variations in ICORs. In order to help address this issue, rather than basing the analysis on mean or individual ICORs, this research uses the median ICOR instead.

The empirical results discussed later in the paper consider the median ICOR over the period between 2000 and 2015 for two main reasons. First, computing a shorter period median reduces the effect of outliers on the results. Second, the median for the period 2000-2015 better reflects the current reality than, for example, using observations from the 1970s. Therefore, throughout the sample, there is one (median) ICOR used to compute the effect of capital flight on economic growth in Saudi Arabia. As such, the median IOCR for the period 2000-2015 is found to be 4.2 percent, and this becomes the fixed denominator to compute the additional growth from investing capital flight (equations 8 and 9).

Using the median ICOR based on historical values to compute the amount of additional output that could be generated by investing flight capital implicitly assumes that additional investment would be as productive as past investment. Following the calculation of the ICOR, the next step is the computation of the effect of capital flight on economic growth. Based on equations (7) and (8), the growth of output attributable to capital flight is:

$$
\Delta G D P_{t}=\frac{K F_{t}}{\pi_{t}}
$$

Where $\triangle G D P$ is additional GDP in real terms in year $\mathrm{t}$ and $\mathrm{KF}$ is the flow of real capital flight from Saudi Arabia in the same year. Therefore, the level of potential GDP incorporating the effect of investing flight capital is:

$$
G D P_{A j d_{t}}=G D P_{t}+\triangle G D P_{t}
$$

With equation (10), the growth of GDP per capita due to capital flight may be computed as:

$$
\triangle G D P P C_{\text {Adjt }}=\frac{G D P_{\text {Adjt }}-G D P_{t}}{\text { Population }_{t}}
$$


On the basis of equation (11), the average annual relative difference in income per capita due to the investment of flight capital is:

$$
g_{C A P}=\frac{1}{n}\left(\sum_{t}^{n}\left(\frac{\triangle G D P P C_{\text {Adjt }}}{G D P P C_{t}}-1\right) * 100\right)
$$

The potential impact of capital flight on the rate of economic growth is computed by considering the period between 1971 and 2015. Hence, the year 1971 is the initial time or beginning of the period of analysis, and 2015 the end of the period, so $\mathrm{n}=43$.

The data used in the computation of this part are annual data and described in the Table A1 in the Appendix.

\section{Discussion and Analysis of Findings}

The results of estimating capital flight from Saudi Arabia are provided in Table 1 and depicted in Figure 1. As shown there, the Saudi economy has experienced a total of 212.6 billion USD of capital flight between 1971-2015. Indeed, some of the annual estimates provided is striking reaching 40 percent of GDP in 1974 and 50, 39 percent of GDP during 1980, 1981, respectively. Those amounts of money represent deep losses of output, forgone domestic investment, and wasted employment opportunities for the Saudi economy.

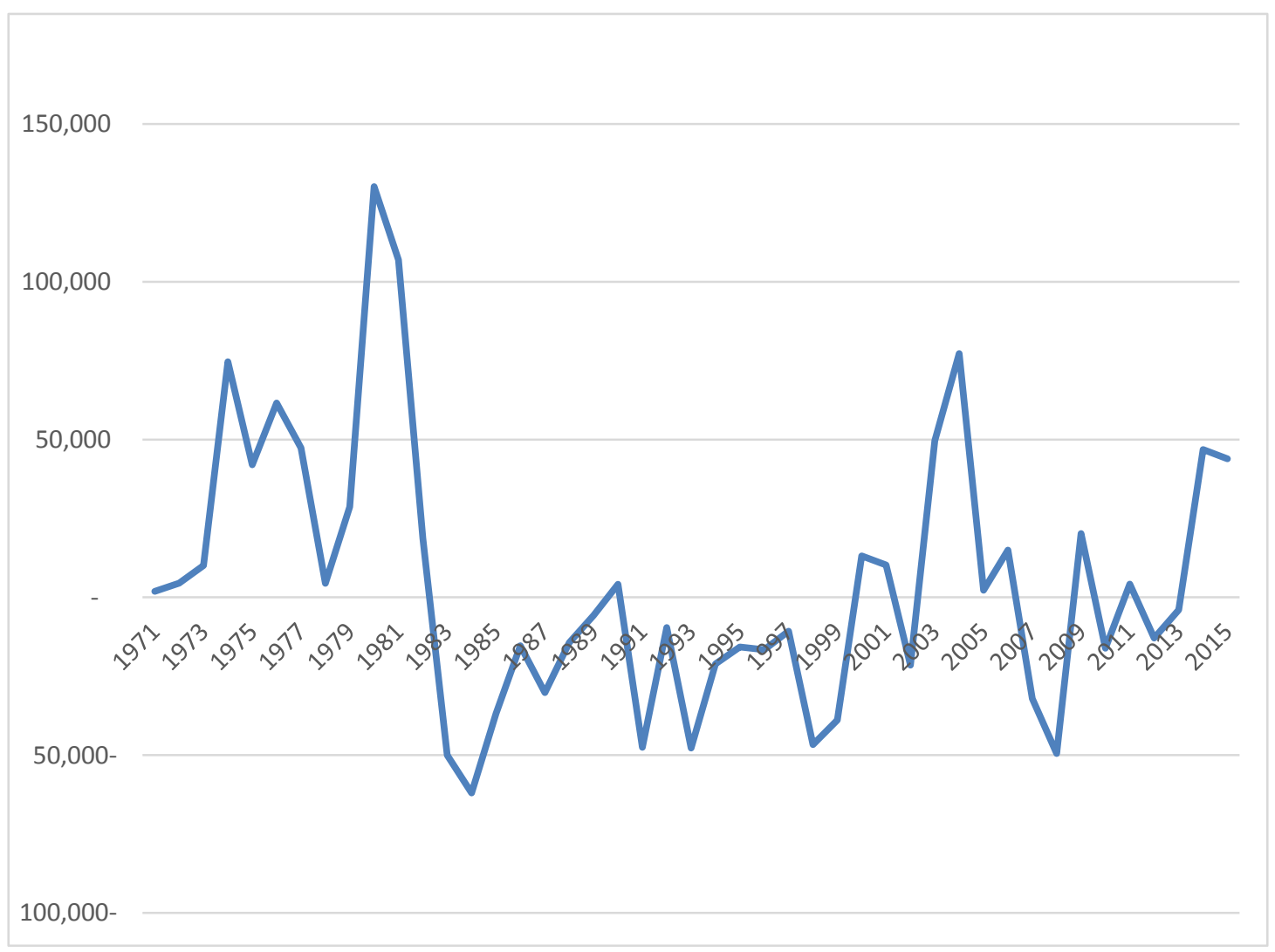

Figure 1. Real Capital Flight from Saudi Arabia in 2010 USD, 1971-2015

A closer look into the details reveals that 405.3 billion of real USD had fled Saudi Arabia in the decade of 1971-1980 alone, suggesting a 'lost decade' indeed for the Saudi economy. If capital flight were invested in the local economy during that decade, it would have generated an extra 5.3 percent of economic growth, on average (Table 2). When considering the median instead, potential lost economic growth becomes 4.98 percent for that decade. The capital flight estimates by decade in Table 2 suggest that most illicit capital outflows took place during the period 1971-1980.

The following two decades (1981-1990, 1991-2000) exhibit rather an opposite direction of illicit capital flows, implying the entrance of large amounts of unregulated foreign exchange into the Saudi economy. This is usually related to trade tax evasion, smuggling activities, and perhaps money laundering, which also need the careful attention of policymakers. 
Table 1. New Estimates of Capital flight from Saudi Arabia, 1971-2015

\begin{tabular}{|c|c|c|c|c|c|}
\hline Year & $\begin{array}{l}\text { Real Capital } \\
\text { Flight (KF) } \\
\text { in Million } \\
2010 \text { USD }\end{array}$ & $\begin{array}{l}\text { Real KF in } \\
\text { Percentage of } \\
\text { Real GDP }\end{array}$ & Year & $\begin{array}{l}\text { Real Capital } \\
\text { Flight (KF) } \\
\text { in Million } \\
2010 \text { USD }\end{array}$ & $\begin{array}{ll}\text { Real KF } & \text { in } \\
\text { Percentage } & \text { of } \\
\text { Real GDP } & \end{array}$ \\
\hline 1971 & 1,881 & 2 & 1999 & $38,877-$ & 13- \\
\hline 1972 & 4,506 & 4 & 2000 & 13,138 & 4 \\
\hline 1973 & 10,069 & 7 & 2001 & 10,239 & 3 \\
\hline 1974 & 74,645 & 40 & 2002 & 21,514 & 7- \\
\hline 1975 & 42,001 & 22 & 2003 & 49,660 & 14 \\
\hline 1976 & 61,594 & 29 & 2004 & 77,251 & 20 \\
\hline 1977 & 47,343 & 21 & 2005 & 2,232 & 1 \\
\hline 1978 & 4,406 & 2 & 2006 & 14,994 & 3 \\
\hline 1979 & 28,699 & 12 & 2007 & $32,081-$ & $7-$ \\
\hline 1980 & 130,157 & 50 & 2008 & 49,463- & $10-$ \\
\hline 1981 & 106,935 & 39 & 2009 & 20,215 & 4 \\
\hline 1982 & 18,716 & 8 & 2010 & $16,150-$ & 3- \\
\hline 1983 & $50,014-$ & $22-$ & 2011 & 4,198 & 1 \\
\hline 1984 & $61,960-$ & $28-$ & 2012 & $12,885-$ & $2-$ \\
\hline 1985 & $36,889-$ & $18-$ & 2013 & $3,998-$ & $1-$ \\
\hline 1986 & $15,326-$ & $7-$ & 2014 & 46,840 & 7 \\
\hline 1987 & $30,207-$ & 14- & 2015 & 43,890 & 7 \\
\hline 1988 & $14,353-$ & 6- & & & \\
\hline 1989 & $5,731-$ & $3-$ & $\begin{array}{c}\text { Total Real } \\
\text { KF }\end{array}$ & 212,613 & \\
\hline 1990 & 4,142 & 2 & & & \\
\hline 1991 & $47,554-$ & $18-$ & $\begin{array}{c}\text { Overall } \\
\text { Average }\end{array}$ & & $1.86 \%$ \\
\hline 1992 & 9,557- & 3- & & & \\
\hline 1993 & $47,732-$ & $17-$ & & & \\
\hline 1994 & $21,107-$ & 7- & & & \\
\hline 1995 & $15,703-$ & 6- & & & \\
\hline 1996 & $16,612-$ & 6- & & & \\
\hline 1997 & $10,736-$ & 4- & & & \\
\hline 1998 & $46,686-$ & 15- & & & \\
\hline
\end{tabular}

Table 2. Potential Additional Growth form Investing Capital Flight in Saudi Arabia, 1971-2015

\begin{tabular}{lllllll}
\hline Year & $\begin{array}{l}\text { Real KF As } \% \\
\text { GDP } \\
\text { (Average) }\end{array}$ & $\begin{array}{l}\text { Actual GDP Per } \\
\text { Capita } \\
\text { In 2010 USD }\end{array}$ & $\begin{array}{l}\text { Potential } \\
\text { GDP Per } \\
\text { Capita }\end{array}$ & $\begin{array}{l}\text { Actual } \\
\text { GDP } \\
\text { Growth } \\
\text { Rate } \\
\text { (Average) }\end{array}$ & $\begin{array}{l}\text { Additional GDP } \\
\text { Growth } \\
\text { Rate } \\
\text { (\% Average) }\end{array}$ & $\begin{array}{l}\text { Additional } \\
\text { GDP } \\
\text { Growth } \\
\%) \\
(\text { Median }\end{array}$ \\
\hline $1971-1980$ & $19 \%$ & 24,364 & 25,532 & $11.78 \%$ & $5.3 \%$ & $4.98 \%$ \\
$1981-1990$ & $-5 \%$ & 17,346 & 21,901 & $-0.46 \%$ & $4.8 \%$ & 4.84 \\
$1991-2000$ & $-8 \%$ & 15,288 & 15,125 & $2.76 \%$ & $0.98 \%$ & $0.98 \%$ \\
$2001-2010$ & $2 \%$ & 16,589 & 16,450 & $5.14 \%$ & $2.3 \%$ & $2.12 \%$ \\
2011-2015 & $2 \%$ & 20,783 & 21,064 & $5.03 \%$ & $1.15 \%$ & $1.55 \%$ \\
$\begin{array}{l}\text { Overall Average } \\
\text { /Median }\end{array}$ & $1.86 \%$ & 18,662 & 21,654 & $4,83 \%$ & $3.57 \%$ & $1.72 \%$ \\
\hline
\end{tabular}

The capital flight estimates for the last period of analysis (2001-2015) show a reversal of direction pointing to unregulated capital outflows once again. During 2001-2015 alone, the Saudi economy experienced more than 146.5 billion of capital flight in real USD, averaging 2 percent of real GDP. This period is rather more complex in terms of economic performance and important economic events. In 2005-2006, the Saudi stock market sharply crashed, while during 2007-08 the global economy slipped into the so-called 'global financial crisis'. In addition, the 'global sovereign debt crisis' emerged in 2010-12. All these events may have been important factors influencing the pattern of capital flight during that period. However, the extent of the impact of such important economic events on Saudi capital flight is an empirical question beyond the scope of this paper.

In terms of forgone output, the Saudi economy lost about 3.5 percent of potential additional growth, on average, during 
2001-2015 because of capital flight. Between 2001-2010, more than 68.5 billion USD ( 2 percent of GDP) has illicitly departed Saudi Arabia, wasting a chance to grow by an additional 2.3 percent, on average. During 2011-2015, yet another 2 percent of GDP of capital flight (78 billion USD) left the economy sacrificing investment opportunities and potential average growth of 1.15 percent.

The overall counterfactual simulations reveal that the period of analysis (1971-2015) has witnessed substantial amounts of capital flight that caused the economy to miss about 3.57 percent of average output growth, or a median of 1.72 percent of lost potential growth. In fact, as presented in Table 2, if the departed funds were geared domestically for productive investment opportunities, real GDP per capita would have become 21,654 (potential) for the same period, instead of 18,662 (actual). The potential total economic growth for the Saudi economy would have been 8.4 percent, instead of the actual average of 4.8 percent had capital flight not taken place as observed. These findings confirm that capital flight has indeed undermined long-term economic performance in Saudi Arabia.

Table 3 presents the estimates of capital flight based on equation 1 instead of equation 5, taking out the effect of trade misinvoicing. Strikingly, the capital flight calculation based on equation 5 is undermined significantly by the amounts of trade misinvoicing. The calculation of misreporting of trade transactions reveal a striking result; massive export overinvoicing and relatively less amount of import underinvoicing.

When disregarding the trade misreporting, total real capital flight for the whole period mounts to 725.7 billion USD, with the last period alone (2000-2015) registering 569 billion USD. Total trade misreporting as shown in Table 3 mounts to more than (-513) billion USD during 1971-2015, suggesting unregulated capital inflows entering the country through trade activities. Although the trading partners' data are available only since 1991, those illegitimate trade practices have intensified since the year 2002 onwards. While capital flight is a drain of the country's resources, trade misreporting in this context indicates illegal cross border capital inflows connected to smuggling, tax evasion activities, and perhaps money laundering, and this requires the immediate attention and prompt action of policymakers.

Table 3. Capital Flight (Excluding Trade Misreporting) \& Potential Growth, 1971-2015

\begin{tabular}{|c|c|c|c|c|c|}
\hline Year & $\begin{array}{ll}\text { Real } & \text { KF } \\
\text { As \% } & \\
\text { GDP } & \\
\text { (Average) } & \end{array}$ & $\begin{array}{l}\text { Trade Misreporting } \\
\text { (Billions of } 2010 \\
\text { USD) }\end{array}$ & $\begin{array}{l}\text { Actual } \\
\text { GDP } \\
\text { Growth } \\
\text { Rate } \\
\text { (Average) }\end{array}$ & $\begin{array}{l}\text { Additional } \\
\text { GDP } \\
\text { Growth } \\
\text { Rate } \\
\text { (\% Average) }\end{array}$ & $\begin{array}{l}\text { Additional } \\
\text { GDP } \\
\text { Growth \% } \\
\text { (Median }\end{array}$ \\
\hline 1971-1980 & $19 \%$ & NA & $11.78 \%$ & $5.3 \%$ & $4.98 \%$ \\
\hline $1981-1990$ & $-5 \%$ & NA & $-0.46 \%$ & $4.8 \%$ & $4.84 \%$ \\
\hline $1991-2000$ & $-5 \%$ & 107.3 & $2.76 \%$ & $2.24 \%$ & $2.24 \%$ \\
\hline $2001-2010$ & $6 \%$ & 173.4 & $5.14 \%$ & $3 \%$ & $2.68 \%$ \\
\hline 2011-2015 & $7 \%$ & 232.3 & $5.03 \%$ & $2.6 \%$ & $2.5 \%$ \\
\hline Overall Average & & & & & \\
\hline /Median & $4 \%$ & 513.2 & $4,83 \%$ & $4.06 \%$ & $2.8 \%$ \\
\hline
\end{tabular}

The capital flight estimates based on equation 1 in Table 3 suggest that potential output growth is even higher when removing the contribution of trade misreporting. Overall, if the 725.7 billion USD of flight capital remained within the Saudi economy and invested with the same productivity as local investment, an average of $4.06 \%$ growth would have been achieved in addition to the actual growth $(4.8 \%)$. As such overall output growth for the Saudi economy in this case would have been about 8.9 percent for the period 1971-2015, instead of the actual 4.8 percent.

\section{Conclusion}

Contemporary economic research has underscored the significance and consequences of capital flight from developing countries. Most importantly, the growth-generating investment capacity is significantly undermined by the illicit transfer of funds abroad. While the intention of capital flights is to finance external private assets, this drain of domestic resources represents forgone economic growth opportunities that would have been realized in the domestic economy. Besides that, capital flight is linked to many other problems such as corruption, tax evasion, weak governance, and social inequality, to name a few.

This research has estimated capital flight from Saudi Arabia over the last four decades and provided a calibration of its social opportunity cost. The large amounts of discovered illicit capital flows is indeed alarming and requires prompt regulation and control of domestic authorities. Had those funds been available locally, the Saudi economy would have realized much higher growth rates and would have achieved higher industrial status among developing countries.

Important policy measures need to be put in place to address illicit capital flight and the associated problems. This requires coordination with trading partners and key investment destination for Saudi capital flows. In addition, the regulatory framework for cross-border financial transactions need to be strengthened and built on best international practices. Combating capital flight would enable a faster growth of capital accumulation thereby sustaining domestic 
productive investment and enhancing balanced economic growth opportunities that promote social and income equality. Such efforts have also the chance of controlling corruption and improving transparency of cross border transactions that have national security considerations and may help pave the way for capital flight reversal to Saudi Arabia.

Important extension of this research would be an econometric analysis of the causes of capital flight (push factors) from Saudi Arabia using the provided estimates in this research. In addition, an analysis of the 'pull factors' of capital flight in the global economic environment would be a valuable contribution to demystifying the dynamics of capital flight in Saudi Arabia. As such, key underlying forces driving the behavior of capital flight would need to be outlined and discussed for a deeper understanding of this phenomenon.

Some of the other important policy suggestions regarding the control of unregulated capital flows as outlined in Kar and Spanjers (2014) are particularly relevant in this context. Financial regulators should require that all banks in their country know the true beneficial owners of any accounts opened in their financial institutions. In addition, regulators and law enforcement should ensure that all of the anti-money laundering regulations are strongly enforced. Policymakers should require public disclosure by multinational companies and should engage in automatic exchange of tax information with trading partners and investment destinations. Lastly, relevant authorities are also strongly recommended to intensify scrutiny of trade transactions and boost customs enforcement to limit trade misreporting and smuggling of traded goods.

\section{References}

Adetiloye, K. A. (2012). Capital Flight versus Domestic Investment in Developing Countries: An Empirical Analysis from Nigeria. International Journal of Economics and Finance, 4(2). https://doi.org/10.5539/ijef.v4n2p175

Ajayi, I. (1997). An Analysis of External Debt and Capital flight in the Severely Indebted Low Income Countries in Sub-Saharan Africa. The International Monetary Fund. WP/97/68. https://doi.org/10.5089/9781451961119.001

Ajayi, I. S. (2012). Capital Flight and Nigeria Economic Growth. Asian Journal of Finance \& Accounting, 4(2).

Almounsor, A. (2005). A Development Comparative Approach to Capital Flight: The Case of the Middle East and North Africa. Capital Flight and Capital Controls in Developing Countries. Edited by Gerald Epstein. Northampton: Edward Elgar Press. 234-261.

Almounsor, A. (2008). Capital Flight Accounting and Welfare Implications in the MENA Region. Review of Middle East Economics and Finance, 4( 2), Article 1. https://doi.org/10.2202/1475-3693.1121

Beja, E. (2007). Capital Flight and Economic Performance. Munich Personal RePEc Archive. MPRA Paper No. 4885

Boyce, J., \& Ndikumana, L. (2000). Is Africa a Net Creditor? New Estimates of Capital Flight from Severely Indebted Sub-Saharan African Countries 1970-1996. Journal of Development Studies. 38(2), 27-56. https://doi.org/10.1080/00220380412331322261

Boyce, J., \& Ndikumana, L. (2010). Measurement of Capital Flight: Methodology and Results for Sub-Saharan African Countries. African Development Review, 22(4), 471-481. https://doi.org/10.1111/j.1467-8268.2010.00243.x

Cuddington, J. T. (1986). Capital Flight: Estimates, Issues, and Explanations. Princeton Studies in International Finance, 58, 1-40.

Epstein, G. (2005). Capital Flight and Capital Controls in Developing Countries. Edward Elgar Publishing. UK.

Kar, D., \& Spanjers, J. (2014). Illicit Financial Flows from Developing Countries: 2003-2012. Global Financial Integrity.

Mpenya, H., Metseyem, C., \& Ngah, E. B. (2015). The Effects of Capital Flight from Oil and Wood Sectors on Economic Growth in Cameroon. University of Yaoundé II, Laboratory of Analysis in Mathematical Research, Centre for Equity Wellbeing and Development Studies.

Ndikumana, L. (2013). Capital Flight and Tax Havens: Impact on Investment and Growth in Africa. Department of Economics and Political Economy Research Institute. University of Massachusetts at Amherst.

Nkurunziza, J. (2014). Capital Flight and Poverty Reduction in Africa. Political Economy Research Institute. Working Paper Number 365. https://doi.org/10.1093/acprof:oso/9780198718550.003.0004

OECD Database, OECD.

Olugbenga, A., \& Alamu, O. (2013). Does Capital Flight Have a Force to Bear on Nigerian Economic Growth? International Journal of Developing Societies, 2(2), 80-86. https://doi.org/10.11634/216817831302422

Onwioduokit, E. (2001). Capital Flight from Nigeria: An Empirical Reexamination. Accra. West African Monetary Institute. Ghana. 
Pastor, M. Jr. (1990). Capital Flight and the Latin American Debt Crisis. Economic Policy Institute. Washington D.C.

Salandy, M., \& Henry. L. (2013). The Impact of Capital Flight on Investment and Growth in Trinidad and Tobago, 1971-2008. Department of Economics. University of the West Indies- St Augustine.

SAMA. (2017). Saudi Arabian Monetary Authorities Annual Database. SAMA. Riyadh.

Weeks, J. (2014). Macroeconomic Impact of Capital Flight in Sub-Saharan Africa. School of Oriental \& African Studies. University of London.

World Bank, Integrated Trade Solutions Database. (2017). The World Bank. Washington DC.

World Bank, World Development Indicators. (2017). The World Bank. Washington DC.

Wujung, V., \& Mbella, M. (2013). Capital Flight and Economic Development: The Experience of Cameroon. Economics, 5(5). 64-72. https://doi.org/10.11648/j.eco.20160505.11

\section{Appendix}

Table A1. Data description

\begin{tabular}{ll}
\hline Variable & Source of Data \\
\hline Net Capital Inflows (NFI) & World Development Indicators (WDI) \\
Current Account Balance (CA) & World Development Indicators (WDI) \\
Change in Reserves (Res) & World Development Indicators (WDI) \\
US Producers' Price Index (PPI) & OECD Database \\
Real Capital Flight (KF) & Authors' Calculations from WDI \& OECD Database \\
Incremental Capital Output Ratio (ICOR) & Authors' Calculations from WDI \& OECD Database \\
PEXP & World Trade Integrated Solutions (World Bank) \\
PIMP & World Trade Integrated Solutions (WITS)- (World Bank) \\
EXP & Saudi Arabian Monetary Authority's database \\
IMP & Saudi Arabian Monetary Authority's database \\
ICXS & Author's calculation from WITS Database \\
ICMS & Author's calculation from WITS Database \\
Growth Rate (g) & World Development Indicators (WDI) \\
Investment (I) - Gross Fixed Capital Formation & World Development Indicators (WDI) \\
Gross Domestic Product (GDP) & World Development Indicators (WDI) \\
Population & World Development Indicators (WDI) \\
GDP per capita & World Development Indicators (WDI) \\
\hline
\end{tabular}

\section{Copyrights}

Copyright for this article is retained by the author(s), with first publication rights granted to the journal.

This is an open-access article distributed under the terms and conditions of the Creative Commons Attribution license which permits unrestricted use, distribution, and reproduction in any medium, provided the original work is properly cited. 